\title{
Upaya Meningkatkan Kemampuan Menulis Melalui Strategi Please
}

\section{Kiuk, Y1*, Suputra, I.G.W' ${ }^{2}$, Adnyani, L. D. S ${ }^{3}$}

${ }^{123}$ Jurusan Pendidikan Bahasa Inggris Universitas Pendidikan Ganesha

\section{ART I CLE I N F O}

Article history:

Received January 21, 2021

Revised February 03, 2021

Accepted April 08, 2021

Available online May 25, 2021

Kata Kunci:
Menulis, Strategi
Pembelajaran, Strategi
PLEASE
Keywords:
Writing, learning strategy,
PLEASE strategy

PLEASE strategy

\begin{abstract}
A B S T R A K
Penelitian berjudul: “Upaya Meningkatkan Kemampuan Menulis melalui Strategi PLEASE bagi Siswa" Permasalahan dalam penelitian ini adalah rendahnya kemampuan peserta didik dalam menulis, khususnya menulis recount text. Penyebabnya adalah peserta didik mengalami kesulitan dalam menuliskan ide, mengorganisasikan ide dan juga masih rendahnya pemahaman tense. Tujuan dari penelitian ini adalah untuk meningkatkan kemampuan peserta didik kelas VIII A-3 SMP Negeri 1 Singaraja dalam menulis recount text dengan penerapan strategi PLEASE.

Meteode penelitian yang digunakan dalam penelitian ini adalah deskriptif kualitatif dan kualitatif. Deskrptif kuantitatif digunakan untuk mendeskripsikan data berupa hasil nilai peserta didik sedangkan descriptive kualitatif digunakan untuk menjelaskan respon siswa terhadap penggunaan strategi PLEASE yang diterapkan. Subjek dalam penelitian ini adalah peserta didik kelas VIII A-3 SMP Negeri 1 Singaraja karena setelah tahap pengamatan dan pretest menunjukan bahwa kemampuan menulis peserta didik di kelas ini sangat rendah. Namun setelah melakukan penerapan strategi PLEASE, peneliti menyimpulkan bahwa adanya peningkatan. Pada pretest, jumlah peserta yang mencapai KKM hanya $31,25 \%$. Sedangkan setelah posttest dilaksanakan rata-rata jumlah peserta didik yang mencapai meningkat dari menjadi $75 \%$ pada siklus 1 dan $78.13 \%$ pada siklus
\end{abstract} 2. Berdasarkan data tersebut maka peneliti menyimpulkan bahwa penerapan strategi PLEASE dalam meningkatkan kemampuan menulis teks recount peserta didik berhasil. Strategi ini bisa dipakai untuk meningkatkan kemampuan menulis peserta didik, bukan hanya dalam menulis teks recount saja, tapi juga bisa untuk kegiatan menulis yang lain.

\begin{abstract}
A BS TRACT
This classroom action research entitled "Increasing the students' writing skill through the implementation PLEASE strategy. This research is conducted based on the students' problems in writing text, in this case recount text. Those problem includes the how to express the idea, how to organise idea dan the using of tense in writing recount text. The aim of this research is to increase the students' skill in writing recount text through the implementation of PLEASE strategy. In this research, the writer used descriptive quantitative and descriptive qualitative method to analyze the data. Descriptive quantitative is used for analyzing and describing about the result of students' writing, whereas descriptive qualitative is used for describing about the students' response to the PLEASE strategy. The subject of this research is students in class VIII A-3. The research took this class as the subject of research because after doing observation and pretest, the writer found that the result of students' writing is too low. Only 31,25\% of the students in the class passed the minimum criteria mastery learning (KKM). After implementing the PLEASE strategy, the score of the students is getting increased. For the first circle posttest the percentage of students that pass the KKM is 75\% and 78.13\% in the second circle posttest.Based on the result of students writing after posttest, the writer concluded that the implementation of PLEASE strategy increases the students' ability in writing. The writer suggested that this strategy can be used as alternative strategy for writing activity.
\end{abstract}

\section{Pendahuluan}

Dalam perkembangan dunia pendidikan, berbagai teori dikembangkan para tokoh pendidikan. Perkembangan tersebut telah memberi warna yang beragam terhadap pola pendidikan. Teori pendidikan empirisme, nativisme dan konvergensi menjadi rujukan dan sumbangsih yang mempengaruhi dalam perkembangan dunia pendidikan (Sholichah, 2018). Pendidikan adalah suatu usaha sadar dan terencana untuk mewujudkan suasana belajar dan proses pembelajaran agar peserta didik da pat aktif mengembangkan potensinya. Sekolah merupakan lembaga formal yang berfungsi mem bantu khususnya orang tua dalam memberikan pendidikan kepada anak-anak mereka. Pendidi kan memberikan pengetahuan, keterampilan dan sikap kepada anak didiknya secara lengkap sesuai dengan yang mereka butuhkan. Pemerintah telah menetapkan Undang-undang Nomor 20 Tahun 2003 tentang Sistem Pendidikan Nasional. Da lam UU tersebut SPN terdapat beberapa potensi akademik yang akan dikembangkan, dimana po tensi tersebut berkaitan dengan karakter. Hal ter sebut dijabarkan dalam 
pasal 3 UU SPN bahwa "Pendidikan nasional berfungsi mengembangkan kemampuan dan membentuk watak serta perada ban bangsa yang bermartabat dalam rangka men cerdaskan kehidupan bangsa, bertujuan untuk berkembangnya potensi peserta didik agar men jadi manusia yang beriman dan bertakwa kepada Tuhan Yang Maha Esa, berakhlak mulia, sehat berilmu, cakap, kreatif, mandiri, dan menjadi warga negara yang demokratis serta bertanggung jawab" (Hasil et al., 2012).

Pendidikan memang untuk manusia, karena hanya manusialah yang dapat di didik. Manusia selain memiliki kemampuan seperti yang dimiliki makhluk lainnya, juga memiliki kemampuan khusus yaitu kecerdasan dan kemauan. Apabila kemampuan khusus tersebut dapat dikembangkan secara optimal, maka manusia itu merupakan makhluk yang paling tinggi derajatnya dan paling mulia kedudukannya. Sebaliknya, bila manusia tidak mendapat pendidikan cukup, maka akan lebih rendah dari hewan. Itulah pendidikan dapat memanusiakan manusia (Rahmayanti, 2016).

Keterampilan menulis merupakan salah satu jenis keterampilan berbahasa yang harus dikuasai siswa. Banyak ahli telah mengemukakan pengertian menulis. Menurut pendapat Saleh Abbas (2006:125), keterampilan menulis adalah kemampuan mengungkapkan gagasan, pendapat, dan perasaan kepada pihak lain dengan melalui bahasa tulis. Ketepatan pengungkapan gagasan harus didukung dengan ketepatan bahasa yang digunakan, kosakata dan gramatikal dan penggunaan ejaan. Pada dasarnya tujuan menulis adalah sebagai alat komunikasi dalam bentuk tulisan. Setiap jenis tulisan tentunya memiliki tujuan (Martha and Situmorang, 2018). Menulis adalah membuat huruf (angka dan sebagainya) dengan pena atau dapat juga diartikan melahirkan pikiran, perasaan, dengan tulisan (Depdiknas 2003:506). Dalam kegiatan menulis ini penulis haruslah terampil memanfaatkan grafologi, struktur bahasa dan kosa kata. Keterampilan menulis dapat dikuasai melalui latihan atau praktik yang banyak dan teratur (Sismulyasih Sb, 2015).

Keterampilan menulis mempunyai peranan yang sangat penting dalam kehidupan sehari-hari. Keterampilan menulis merupakan syarat untuk berkecimpung dalam berbagai macam bidang atau kegiatan. Hal ini mengandung pengertian betapa pentingnya keterampilan dan kemampuan menulis dalam kehidupan sehari-hari. Menulis juga merupakan salah satu keterampilan berbahasa yang dipergunakan dalam komunikasi secara tidak langsung. Melalui kegiatan menulis, siswa diarahkan mampu berkomunikasi dengan menggunakan bahasa tulis. Dalam hal ini, diharapkan siswa mampu menuangkan gagasan atau idenya secara runtut dengan diksinya yang tepat, struktur yang benar sesuai dengan konteksnya.Dalam pembelajaran menulis, salah satu kompetensi dasar yang akan dikaji oleh peneliti adalah kegiatan menulis kembali dongeng pada aspek kesusastraan. Kompetensi dasar tersebut yang harus ditempuh oleh siswa kelas VII semester I untuk mencapai salah satu tujuan pembelajaran. Melalui standar kompetensi tersebut siswa diharuskan untuk mampu mengubah dongeng yang pernah dibaca dengan cara menulisnya kembali sesuai dengan bahasanya sendiri (Puspitasari and Rustono, 2014).

Pendidikan nilai merupakan salah satu komponan dalam pendidikan kewarganegaraan yang tidak hanya mendidik para peserta didiknya untuk menjadi manusia yang cerdas, tetapi juga membangun kepribadiannya agar memiliki akhlak mulai. Saat ini pendidikan nilai di Indonesia dinilai tidak masalah dengan peran pendidikan dalam mecerdaskan para peserta didiknya, namun dinilai kurang berhasil dalam membangun kepribadian peserta didik agar berakhlak mulia (Arsyad, 2016).

(Wiyanto, 2006) mengatakan mengatakan bahwa menulis adalah mengungkapkan gagasan secara tertulis. Orang yang melakukan kegiatan ini dinamakan penulis dan hasil kegiatannya berupa tulisan. Tulisan dibuat untuk dibaca orang lain agar gagasan yang disampaikan penulis dapat diterima oleh pembaca. Kegiatan menulis itu menekankan pada kemahiran dalam menuangkan ide, gagasan, pendapat, isi hati, dan perasaan secara runtut yang bermediakan bahasa tulis. Kegiatan tersebut diperlukan dalam usaha agar orang lain merasa perlu mengetahui dan menikmati tujuan utama penuangan ide, gagasan, pendapat, isi hati atau perasaan penulis. Dengan demikian, dalam komunikasi tulis paling tidak terdapat empat unsur yang terlibat. Empat unsur tersebut penulis sebagai penyampai pesan (penulis), pesan atau isi tulisan, saluran atau media berupa tulisan, dan pembaca sebagai penerima pesan. Untuk itu agar pesan yang ingin disampaikan dapat diterima dengan baik oleh pembaca, maka tulisan yang dibuat juga harus jelas dan mudah dimengerti.

Menulis dapat dianggap sebagai suatu proses maupun suatu hasil. Menulis merupakan kegiatan yang dilakukan oleh seseorang untuk menghasilkan sebuah tulisan yang berisi tentang ide dan gagasan mereka. Dengan menulis juga, ide yang ingin penulis lebih terarah, tidak terburu-buru dan juga penulis merasa lebih leluasa untuk berekspresi melalui tulisannya. Semulis merupakan kegiatan yang sangat mudah atau gampang bagi sebagian orang, tetapi tidak sedikit juga yang mengganggap bahwa menulis merupakan kegiatan yang susah. Hal ini didukung oleh Heaton. Menurut Heaton dalam St. Y. Slamet (2008:141) menulis merupakan keterampilan yang sukar dan kompleks. Selain Heaton, McCrimmo juga memberikan argument yang sama. Menulis menurut McCrimmon dalam St. Y. Slamet (2008: 141) 
merupakan kegiatan menggali pikiran dan perasaan mengenai suatu subjek, memilih hal-hal yang akan ditulis, menentukan cara menuliskannya sehingga pembaca dapat memahaminya dengan mudah dan jelas. St. Y. Slamet (2008:72) sendiri mengemukakan pendapatnya tentang menulis yaitu kegiatan yang memerlukan kemampuan yang bersifat kompleks.

Menurut O'Malley dan Pierce ada tiga tujuan utama menulis berdasarkan jenis tulisanya dalam pembelajaran Bahasa Inggris. Yang pertama adalah Informatif. Informatif yaitu untuk memberikan informasi tentang sesuatu. Informasi tersebut dapat berupa pengetahuan dan petunjuk. Tulisan informatif termasuk menjelaskan suatu peristiwa atau kejadian, Analisa konsep, pengembangan berita dengan tujuan memberikan informasi yang penting kepada orang lain. Kedua, ekspresif atau naratif. Disebut juga tulisan narrative, kegiatan menulis ini bertujuan untuk menggungkapkan ide imajinative dari penulis yang biasanya bertujuan untuk sekedar menghibur pembaca dan bersifat fiksi. Ketiga yaitu persuasive. Tujuan dari kegiatan menulis tulisan ini adalah untuk membujuk atau meyakinkan seseorang untuk melakukan sesuatu. Jenis tulisan ini dapat berupa evaluasi terhadap suatu film, buku atau suatu produk tertentu.

Menulis adalah suatu proses kreatif yang dilakukan melalui tahapan yang harus dikerjakan dengan mengerahkan keterampilan, seni, dan kiat sehingga semuanya berjalan dengan efektif. Kegiatan menulis diibaratkan sebagai seorang arsitektur yang akan membangun sebuah gedung. Sebuah sistem kerja yang kreatif memerlukan langkahlangkah yang tersusun secara sistematis. Kegiatan menulis juga memerlukan tahapan-tahapan tertentu di dalam prosesnya. Tahaptahapan menulis menurut M. Atar Semi (2007: 46) terbagi menjadi tiga, yaitu a) tahap pratulis, b) tahap penulisan, dan c) tahap penyuntingan.

Menurut Elina Syarif, Zulkarnaini, dan Sumarno (2009: 11) tahap-tahap menulis terdiri dari enam langkah, yaitu: a) draf kasar, b) berbagi, c) perbaikan, d) menyunting, e) penulisan kembali, f) evaluasi. Dari pendapat tersebut di atas dapat disimpulkan mengenai tahap-tahap dalam menulis yaitu: Tahap Pratulis. Tahap pratulis merupakan tahap paling awal dalam kegiatan menulis. Tahap ini terletak pada sebelum melakukan penulisan. Di dalam tahap pratulis terdapat berbagai kegiatan yang dilakukan oleh penulis. Mulai dari menentukan topik yang akan ditulis. Penulis mempertimbangkan pemilihan topik dari segi menarik atau tidaknya terhadap pembaca. Kedua, tahap pembuatan draf. Draf yang dimaksud adalah tulisan yang disusun secara kasar. Pada kegiatan ini penulis lebih mengutamakan isi tulisan dari pada tata tulisnya sehingga semua pikiran, gagasan, dan perasaan dapat dituangkan ke dalam tulisan. Ketiga, tahap revisi. Merevisi berarti memperbaiki, dapat berupa menambah yang kurang atau mengurangi yang lebih, menambah informasi yang mendukung, mempertajam perumusan penulisan, mengubah urutan penulisan pokok-pokok pikiran, menghilangkan informasi yang kurang relevan, dan lain sebagainya. penulis berusaha untuk menyempurnakan draf yang telah selesai agar tulisan tetap fokus pada tujuan. Keempat, tahap penyuntingan. Pada tahap penyuntingan penulis mengulang kembali kegiatan membaca draf. Tulisan pada draf kasar masih memerlukan beberapa perubahan. Kegiatan selama tahap penyuntingan adalah meneliti kembali kesalahan dan kelemahan pada draf kasar dengan melihat kembali ketepatannya dengan gagasan utama, tujuan penulisan, calon pembaca, dan kriteria penerbitan.

Meskipun menulis dilihat sebagai suatu kegiatan ekspresif yang cukup menyenangkan, namun menulis masih menjadi kegiatan yang sulit bagi sebagian orang, khususnya bagi siswa SMP N 1 Singaraja kelas VIII dalam penulisan recount text. Kesulitan yang dihadapi siswa SMP N 1 Singaraja kelas VIII A-3 ini dapat dilihat dalam hasil tulisan recount text siswa yang mereka buat saat mereka mendapat tugas menulis recount text tentang pengalaman mereka saat liburan sekolah. Dari hasil tulisan siswa, dapat dilihat bahwa isi dan ide tulisannya belum dikembangkan dengan benar; bahkan tulisanya hanya terdiri dari beberapa kalimat dan kalimat tersebut juga tidak berkesinambungan. Gejala lain yang ditemukan yaitu, kejadian dalam tidak tersusun menurut kronologinya. Tulisan siswa juga ada yang tidak menggambarkan pada topik yang dibahas.

Dan ternyata dari kegiatan menulis recount teks tersebut hanya ada 31\% dari siswa kelas VIII A-3 SMP N 1 Singaraja yang berhasil menulis teks recount dengan cukup baik. Berdasarkan hasil pengamatan dan wawancara beberapa siswa, kesulitan yang dihadapi siswa dalam menulis recount text disebabkan oleh ketidakmampuan siswa dalam mengelolah ide yang ada dalam pikiran mereka kemudian membahasakannya dalam bentuk tulisan, siswa tidak tahu bagaimana harus memulai tulisannya dan juga siswa kesulitan mengevaluasi tulisan mereka sendiri. Sebenarnya dalam penulisan recount text, para peserta didik diminta menulis pengalaman atau kejadian yang mereka alami, rasakan atau yang mereka tahu. Selain karena karena kesulitan diatas, masalah lain yang dihadapi siswa juga bisa disebabkan oleh cara mengajar guru dan strategi pembelajaran yang kurang tepat. Teks recount adalah teks yang menceritakan kejadian atau pengalaman yang benar - benar terjadi dimasa lampau dengan tujuan memberi informasi dan atau menghibur pembaca. Hal ini menunjukan bahwa siswa sebenarnya tahu pasti 
apa yang mereka harus tulis akan tetapi hasil tulisan siswa menunjukan hal yang berbeda; siswa sepertinya tidak tahu apa yang akan mereka tulis.

Untuk mengatasi kesulitan siswa dalam menulis recount text, dalam penelitian ini penulis mengatasi masalah yang dihadapi siswa dengan strategi PLEASE. Strategy PLEASE merupakan singkatan dari $(\mathrm{P})=$ Pick your topic,$(\mathrm{L})=$ List your ideas about the topic, $(\mathrm{E})=$ Evaluate your list, $(\mathrm{A})=$ Activate the paragraph, $(S)$ = Supply supporting sentences, $(E)=$ End with a concluding sentence and evaluate work. Strategi ini didesain untuk menfasilitasi siswa dalam kegiatan menulis mandiri bagi siswa; siswa memilih topik yang ingin mereka tulis kemudian membuat list tentang apa yang akan mereka tulis. Setelah itu mereka mulai mengembangkanya. Pembuatan list tentang ide tulisan yang akan ditulis sangat membantu siswa untuk pengembangan tulisan ke dalam paragraph dan dapat membantu siswa untuk mengurutkan kronologi kejadian yang akan mereka tulis. Siswa juga dapat melakukan evaluasi dengan membaca kembali tulisan mereka sendiri atau tulisan temannya dan memberikan masukan atau mengoreksi tata bahasa tulisan tersebut. Harapan penulis setelah melakukan PTK, siswa dapat dengan mudah mengelolah ide pikiran mereka dan menuangkannya dalam bentuk tulisan yang baik dan lebih terstruktur serta mampu melakukan evaluasi terhadap tulisan mereka.

\section{Metode}

Subjek penelitian yang menjadi sasaran dalam Penelitian Tindakan Kelas ini adalah siswa kelas VIII A-3 SMP N 1 Singaraja. Dengan jumlah siswa terdiri dari 32 orang dimana terdiri dari perempuan 13 siswa dan laki-laki 19 siswa. Penelitian ini dilaksanakan pada tahun ajaran 2018/2019 tepatnya pada bulan Maret 2019 sampai dengan Mei 2019. Sebelum pelaksanaan PTK dibuat, ada beberapa hal yang perlu dipersiapkan untuk mendukung pelaksanaan PTK tersebut antara lain Rencana Pelaksanaan Pembelajara yang terkait dengan topik yang ingin diteliti. Dalam hal ini RPP tentang recount text yang merujuk pada kompetensi dasar (KD) 3.11 dan 4.11 yang ada dalam silabus pembelajaran Bahasa Inggris untuk SMP kelas VIII. Selain RRP, peneliti juga menyiapkan lembar observasi dan lembar evaluasi untuk siswa. Teknik analisis data yang digunakan dalam penelitian ini ada dua yaitu (1) Analisis Deskriptif Komparatif. Analisis deskriptif komparatif artinya membandingkan hasil belajar yang dicapai anak kondisi awal dengan pencapaian hasil belajar setelah mendapat perlakuan. (2) Analisis Deskriptif Kualitatif. Analisis dekriptif kualitatif dari tiap siklus, yang selanjutnya direfleksi untuk membandingkan haisl pengamatan siklus I dan siklus II.

Penelitian tindakan kelas ini akan dilakukan dalam dua siklus yang masing-masing siklus memiliki tahap perencanaan, pelaksanaan tindakan, pengamatan dan refleksi. Dalam siklus 1, ada beberapa tahap yaitu: (1) Perencanaan. Perencanaan (Planning). Rencana kegiatan yang akan dilakukan adalah antara lain yang pertama, menyusun Rencana Pelaksanaan Pembelajaran (RPP) yang berkaitan dengan topik dan strategi yang akan digunakan dalam pelaksanaan pembelajaran. Kedua, membuat dan menyiapkan instrumen nontes berupa lembar observasi, lembar wawancara, dan yang terakhir menyiapkan perangkat penilaian, penskoran dan analisis. (2) Pelaksanaan Tindakan. Tindakan pada tahap siklus I direncanakan 2 kali pertemuan atau 4 x 40 menit. Pada pertemuan pertama, (a) Guru menjelaskan konsep pembelajaran dengan menjelaskan urutan tugas yang dikerjakan siswa serta procedur dari strategi PLEASE yang nanti akan digunakan. (b) Guru meminta siswa untuk memikirkan kegiatan yang mereka lakukan beberapa hari yang lalu - Pick (pada kegiatan ini guru memfokuskan agar topik yang akan ditulis oleh para peserta didik sama atau selaras) (c) Guru meminta siswa untuk membuat list kegiatan yang telah mereka lakukan beberapa hari lalu dalam bentuk kalimat sederhana. Siswa diminta minimal membuat 5 daftar kalimat ang berkaitan denga kegiatan yang mereka lakukan - List (d) Siswa mengevaluasi kalimat yang telah mereka buat dengan memperhatikan kronologi kegiatanya serta grammar atau tata Bahasa yang digunakan Evaluate. Dalam keempat aktivitas diatas guru atau peneliti bertugas untuk membimbing dan memfasilitasi siswa dalam proses kegiatan belajar mengajarnya. Pada pertemuan kedua, aktivitas yang dilakukan oleh siswa masih menjadi lanjuatan dari kegiatan yang dilakukan pada pertemuan pertama. Pada pertemuan ini, kegiatan yang dilakukan adalah (e) Siswa diminta untuk mengembangkan kalimat yang telah mereka buat sebelumnya kedalam bentuk paragaf - Activate. (f) Siswa kemudian mengembangkan lebih lebih lanjut paragraf mereka dengan menambahkan kalimat pendukung untuk ide dalam paragraf yang mereka tulis - Supply (g) Siswa kemudian menutup paragrafnya dengan kesimpulan (reorientation) serta mengevaluasi hasil tulisan mereka dari awal - End. Pada siklus pertama ini, peneliti mengenalkan strategi yang digunakan dan juga masih membantu siswa dengan memberikan guide dalam hal pemilihan topik dan pelaksanaan penulisan sehingga siswa lebih mudah dalam penulisan. Hal ini juga dilakukan agar siswa memiliki gambaran yang jelas tentang apakah yang harus mereka tulis nanti. (3) Pengamatan. Penulis mengamati dan mencatat semua kegiatan siswa dalam proses belajar mengajar writing dengan menggunakan strategi PLEASE saat tes tertulis berlangsung. Selain mencatat kegiatan siswa selama kegiatan pembelajaran, penulis juga mencatat kesulitan yang masih sering ditemui siswa 
dalam kegiatan yang dilakukan. (4) Refleksi. Kegiatan ini menganalisa data yang diperoleh baik yang berupa data kauntitatif atau pun kualitatif. Hasil dari analisa tersebut dijadikan dasar untuk membuat perencanaan sistem pembelajaran yang lebih bagus dan menarik. Untuk diterapkan pada siklus II.

Pada Siklus 2 juga ada beberapa tahap yaitu: (1) Perencanaan. Pada perencanaan siklus kedua ini, hamper sama dengan perencanaan pada siklus pertama. Yang berbeda pada sklus ini adalah hanya topik pada RPP. (2) Pelaksanaan Tindakan. Pada tahap pelaksanaan, kegiatan yang dilakuakan masih sama seperti pada siklus pertama. Yang berbeda hanyalah pemilihan topik pada kegiatan menulis yang akan dilakukan. Sebelumnya pada siklus pertama penulis selaku guru menyelaraskan topik yang akan dipilih oleh siswa sedangkan pada siklus ini, siswa bebas untuk memilih topik yang akan dipakai dalam kegiatan menulis mereka. (3) Pengamatan. Penulis mengamati dan mencatat semua kegiatan siswa dalam proses belajar mengajar writing dengan menggunakan strategi PLEASE saat tes tertulis berlangsung. Selain mencatat kegiatan siswa selama kegiatan pembelajaran, penulis juga mencatat kesulitan yang masih sering ditemui siswa dalam kegiatan yang dilakukan. (4) Refleksi. Kegiatan ini menganalisa data yang diperoleh baik yang berupa data kauntitatif atau punkualitatif. Hasil dari analisa tersebut dijadikan dasar mengukur tingkat keberhasian strategi yang digunakan.

\section{Hasil Dan Pembahasan}

Pelaksanaan PTK ini didasarkan pada hasil pengamatan dan pretest yang dilakukan sebelum penentuan selusi pembelajaran yang akan terapkan untuk mengatasi masalah yang dihadapi peserta didik dalam menulis. Pengamatan ini dilakukan di kelas diasuh sendiri oleh penulis, yakni kelas VIII A-3 SMP Negeri 1 Singaraja. Pengamatan dilaksanakan dua tahap yakni tahap pertama dilaksanakan pada tanggal 28 Februari 2019. Sedangkan tahap kedua dilaksanakan pada tanggal 26 Maret 2019.

Pengamatan tahap pertama berlangsung saat kegiatan menulis daily activity yang berhubungan dengan simple present tense. Meskipun pada kegiatan menulis ini tense yang digunakan berbeda dengan tenses yang digunakan pada teks yang akan diteliti, yakni recount text, penulis dapat menilai kemampuan pengelolahan dan pengembangan peserta didik pada kesmpatan ini. Dalam kegiatan ini, peneliti menemukan bahwa banyak siswa masih belum bisa menulis tentang kegiatan mereka sehari-hari dengan benar. Ide yang ingin mereka tulis sebenarnya sedah bagus akan tetapi cara penyampain lewat tulisan ini yang masih menjadi masalah. Kronologis kegiatan yang mereka tulis juga belum beruntun atau tesusun secara teratur, sehingga masih terasa janggal dalam tulisan mereka. Selain itu juga, peserta didik masih memiliki permasalahan pada pemilihan kata dan penggunaan tense yang tepat untuk menggambarkan ide yang mereka punya.

Setelah meakukan pengamatan tahap pertama, peneliti kemudian melakukan pengamatan kedua yang yang dilaksanakan pada tanggal 26 Maret 2019. Pada saat pengamatan, materi ang sedang dipelajari para siswa adalah materi tentang recount text, hasil dari pengamatan ini masig sama dengan permaslahan yang dihadapi pada pengamatan pertama. Selain masalah pengorganisasian gagasan, salah satu masalah utama yang dihadapi peserta didik dalam kegiatam menulis recount text adalah penggunaan tense yang tepat. Dalam penulisan recount text, tense yang digunakan adalah past tense. Materi tentang Past tense sebenarnya sudah dipelajari peserta didik pada topik sebelumnya, namun nyatanya penggunaan past tense dalam penulisan recount text juga masih menjadi kendala utama.

Setelah melakukan dua kali pengamatan, peneliti melakukan pretest untuk memastikan apakah masalah yang ditemukan di dalam kelas menulis benar-benar ada atau tidak. Pretest juga dilaksanakan guna mendapatkan data awal peserta didik yang nantinya akan dipakai sebagai bahan acuan dan perbandingan dengan hasil yag didapat peserta didik setelah PTK dilaksanakan. Setelah melakukan pretest dan mengevaluasi hasil pre tes peserta didik, penulis menemukan bahwa ternyata sebagian siswa belum mencapai kriteria ketuntasan minimal (KKM). KKM yang ditetapkan sekolah adalah 78 dari 100. Sedangkan dari hasil hasil pretest siswa menunjukan bahwa jumlah siswa yang mencapai KKM masih belum mencapai minimal $75 \%$. Total dari 32 peserta didik yang menjadi subjek penelitaian, hanya 10 siswa yang mecapai KKM atau hanya 31,25\% dari total seluruh siswa. Sedangkan untuk peserta didik yang tidak mencapai KKM, terdapat 22 peserta didik atau $68,75 \%$ dari total seluruh peserta didik

Berdasarkan hasil dari pelaksanaann pretest maka dapat disimpulakan bahwa rata-rata nilai siswa belum mencapai KKM yang dipakai disekolah. Rata-rata nilai yang diperoleh siswa adalah 71,09 yang mana masih sangat jauh dari kroteria yang ditetapkan. Dalam menilai hasil tulisan peserta didik, peneliti menggunakan rubrik yang mencakup lima aspek utama yang akan dinilai yaitu, Content (isi), Organization (Penggorganisasian), Grammar (tata Bahasa), Vocabulary (pemilihan kata), Mechanics (mekanisme). Berdasarkan data yang diperoleh makan yang menjadi kekuarangan peserta didik adalah aspek grammar (tata Bahasa) dari total bobot maksimal 4 (empat), rata-rata skor yang didapat peserta didk untuk aspek ini adalah yang paling rendah dengan skore 2,47. Diikuti dengan Organization (Penggorganisasian) dengan rata-rata skor 2,66. Di urutan ketiga ada Vocabulary (pemilihan kata) dengan rata-rata skore 2,91 
dan secara berurutan ada aspek Content (isi) dan Mechanics (mekanisme) dengan rata-rata skor 3.03 dan 3.16 .

Berdasarkan hasil analisis tersebut dapat disimpulkan bahwa kemampuan siswa dalam penulisan masih rendah. Siswa masih mengalami permasalahan pada penggunaan tense, penggorganisasian gagasan, dan juga pemilihan kata. Merujuk pada kendala yang dihadapi peserta didik tersebut maka peneliti menerapkan penggunaan strattegi PLEASE guna membantu siswa untuk mengatasi permasalahan tersebut. Dalam penerapan strategi ini, peneliti membutuhkan dua siklus ang mana tiap siklusnya terdiri dari dua pertemuan. Setelah melaksanakan posttest siklus 1 dapat didisimpulkan bahwa setelah menerapkan strategy please dalam kegiatan pembelajaran dan penulisan recount text, dapat disimpilkan bahwa perkembagan siswa mengalami peningkatan dengan rincian sebagai berikut dari 32 siswa pada kelas VIII A-3 yang mencapai KKM untuk penulisan recount text sebanyak 24 orang, sedangkan 8 orang lainnya belum mencapai KKM. Hasil ini sudah meningkat drastis dari hasil pretest sebelumya. Berbanding lurus dengan jumlah siswa yng mencapai KKM mengalami peningkatan, nilai rata-rata peserta didik juga mengalami peningkatan yang mana dari skor 71,39 menjadi 83,79. Berikut adalah presentasi nilai atau hasil penulisan siswa pada Siklus I: untuk nilai 0-77 dicapai oleh 8 orang atau sekitar 25\%, selanjutnya nilai 78-84 dicapai oleh 9 orang atau sekitar 28,12\%, dan terakhir untuk nilai 85-100 dicapai oleh 15 orang atau sekitar $46,87 \%$

Hasil posttest pada Siklus I menunjukan bahwa peserta didik yang mencapai KKM adalah 24 peserta didik atau sekitar $75 \%$ dari peserta didik yang berjumlah 32 orang di kelas VIII A-3. Hal ini menenunjukan 224 siswa atau sekitar 75\% telah mencapai KKM. Hal ini menunjukan bahwa penerapan strategi PLEASE dalam kegiatan menulis recount text mengindikasikan keberhasilan. meskipun demikian, masih juga ditemui beberapa siswa yang belum mencapai KKM yang telah ditetapkan. selain itu juga masih terdapat beberapa kekurangan yang ditemui peneliti dalam hasil tulisan peserta didik. Kekurangan tersebut akan disjelaskan sebagai berikut.

Pertama, adalah penggunaan tense yakni past tense dalam menulis. Tenses adalah kekurangan utama dalam menulis recount text bagi peserta didik kelas VIII A-3 SMP Negeri 1 Singaraja. Siswa masih sering slah menggunakan kata kerja yang tepat sesuai dengan perubahan kedalam bentuk past tense-nya. Untuk itu pada pertemuan berikutnya, peneliti ingin menekankan pada penggunaan past tense yang yang benar agar peserta didik dapat menghindari kesalahan yang sama pada siklus berikutnya. Rataan bobot yang diperoleh peserta didik untuk aspek tata Bahasa adalah 2,94 yang mana menjadi nilai rataan paling rendah jika dibandingkan dengan aspek yang lain.

Masalah yang kedua adalah pengorganisasian paragraf. Paragraf yang ditulis oleh siswa harusnya minimal terdiri dari dua atau tiga paragraf dimana paragraf pertama adalah orientasi, paragraf kedua adalah daftar kegiatan atau rincian kegiatan yang dilakukan, dan paragraf ketiga yan biasa ada ataupun bisa ditiadakan berisi tentang kesan atau kesimpulan dari cerita yang peserta didik tulis. Meskipun demikian, untuk kejelasan cerita yang diceritakan oleh peserta didik cukup jelas dengan rataan skor untuk Organization adalah 3,34 dari total skor 4.

Untuk aspek penilaian yang lain, nilai rataan yang didapat peserta didik sudah cukup bagus. Meskipun begitu, setelah melakukan diskusi dengan kerabat guru, peneliti menetapkan bahwa akan melanjutkan PTK ini ke siklus kedua guna mengkonfirmasi kembali keberhasilan yang didapat oleh peserta didik serta juga untuk berusaha melihat kekurangan yang masih ada dalam siklus kedua untuk diperbaiki lagi.

Setelah melakukan posttest pada Siklus 2 dapat didisimpulkan bahwa setelah menerapkan strategy please dalam kegiatan pembelajaran dan penulisan recount text, dapat disimpulkan bahwa perkembagan siswa mengalami peningkatan dengan rincian sebagai berikut dari 32 siswa pada kelas VIII A-3 yang mencapai KKM untuk penulisan recount text sebanyak 25 orang, sedangkan 7 orang lainnya belum mencapai KKM. Hasil ini menunjukan peningkatan jika dibandingkan dengan hasil pada siklus pertama. Pada siklus pertama jumlah peserta didik yang mencapai KKM adalah 24 orang dan kemudian meningkat menjadi 25 orang pada siklus kedua ini. Meskipun tidak mengalami peningkatan yang signifikan, dapat dikatakan bahwa penerapan strategi ini mampu memberikan dampak yang sangat positif bagi kegiatan pembelajaran khususnya untuk kegiatan menulis. Berikut adalah presentasi nilai atau hasil penulisan siswa pada Siklus I: untuk nilai 0-77 dicapai oleh 7 orang atau sekitar $21,87 \%$, selanjutnya nilai $78-84$ dicapai oleh 9 orang atau sekitar 28,12\%, dan terakhir untuk nilai 85-100 dicapai oleh 16 orang atau sekitar $50 \%$

Hasil post test pada Siklus 2 menunjukan bahwa peserta didik yang mencapai KKM adalah 25 peserta didik atau sekitar $78.13 \%$ dari peserta didik yang berjumlah 32 orang di kelas VIII A-3. Hal ini menenunjukan 25 siswa telah mencapai KKM. Sehingga dapat dikatakan bahwa penerapan strategi PLEASE dalam kegiatan menulis recount text mengindikasikan keberhasilan. meskipun demikian, masih juga ditemui beberapa siswa yang belum mencapai KKM yang telah ditetapkan. selain itu juga masih 
terdapat beberapa kekurangan yang ditemui peneliti dalam hasil tulisan peserta didik. Kekurangan tersebut akan disjelaskan sebagai berikut. Meskipun yang masih menjadi kendala dalam penulisan recount text adalah penggunaan tense.

Pada siklus ini peneliti sudah membantu peserta didik dengan memberikan pemahaman tambahan tentan past tense sebelum dan selama pembelajaran berlangsung. Meski pen begitu, secara keselurahan dapat disimpulkan bahwa penggunaan stategy PLEASE dalam kegiatan menulis recount text dinyatakan berhasil. Setelah membandingkan hasil pretest dan posttest siklus 1 dapat disimpulkan bahwa presentase kelulusan peserta didik setelah penerapan strategi PLEASE pada siklus 1 mengalami peningkatan sebanyak $43 \%$. Pada pre test, jumlah peserta didik yang mencapai KKM adalah 10 orang atau hanya $31,25 \%$ dari total jumlah peserta didik secara keseluruhan. Peningkatan ini mengindikasikan bahwa permasalahan yang ditemui peserta didik dalam menulis recount text sudah muali teratsasi dengan strategi PLEASE yang digunakan. Secara keseluruhan, pengorganisasian ide, penggunaan tata Bahasa peserta didik juga mulai membaik. Peserta didik terbantu dengan adanya kegiatan membuat draft atau daftar ide sebelum menuangkannya kedalam bentuk paragraf. Dengan membuat daftar ide terlebih dahulu, peneliti menemukan bahwa peserta didik lebih muda menganalisa kesalahan tata Bahasa yang mereka buat. Selain itu juga, kegiatan membuat daftar ide ini sangat membantu peserta didik untuk mengingat gagasan yang ada dalam cerita yang ingin mereka tulis.

Merujuk pada jumlah peserta didik yang mencapai KKM setelah penerapan strategi ini, peneliti mengambil kesimpulan bahwa respon siswa terhadap penggunaan strategi ini sangatlah positif. Peserta didik yang awalnya hanya 10 orang yang mencapai KKM pada tahap pretest bertambah 14 orang lagi sehingga pada post test siklus 2 ditemukan bahwa jumlah peserta didik yang mencapai KKM telah menjadi 24 orang. Hal ini menunjukan bahwa masalah-masalah yang sering dihadapi peserta didik dalam menulis perlahan-lahan dapat diatasi lewat penerapan strategi PLEASE. Sebagian besar siswa merasa terbantu dalam memahami serta meningkatkan keterampilan mereka untuk menulis recount text. strategi ini memberikan banyak kesempatan bagi siswa untuk berlatih dan mengevaluasi sendiri hasil tulisan recount text yang mereka buat.

\section{Simpulan}

Setelah melakukan PTK dan merujuk pada hasil penelitian yang telah diperoleh selama melakukan proses penelitian yang nenekankan pada penggunaan startegi PLEASE meningkatkan kemampuan menulis recount text peserta didik VIII A-3 SMP Negeri Singaraja, maka dapat disimpulkan bahwa penggunaan strategi please dalam kegiatan menulis recount text sudah berhasil. Pernyataan ini merujuk pada hasil post test yang telah didapat setelah penerapan strategi dilaksanakan.

Strategi please merupakan slah satu strategi menulis yang memiliki prosedur yang mudah untuk diikuti dan sangat berguna bagi penulis khusuhnya penulis pemula seperti peserta didik kelas VIII A-3 untuk menulis secra rinci dan terurut. Penulis juga dapat melakukan evaluasi secara beruntun untuk merevisi hasil tulisan mereka secara bertahap. Berdasarkan hasil yang diperoleh, peserta didik mengalami peningkatan dalam menulis recount text setelah strategi please ini di terapkan. Pada pre test yang dilaksanakan sebelum penelitian tindakan kelas dimulai, rata-rata pencapaian peserta didik dalam menulis recount text adalah 71,09 dimana KKM untuk mata pelajaran Bahasa Inggris adalah 78. Ini berarti peserta didik belum mencapai KKM yang ditetapkan. namun setelah menerapkan strategi please dalam kegiatan menulis, rata-rata nilai siswa meningkat menjadi 83.79 pada siklus 1 dan 84.02 pada siklus 2 .

Hal ini menunjukan bahwa indicator pencapaian untuk kegiatan menulis tercapai setelah penerapan strategi please dalam menulis recount text. selain merujuk pada nilai hasil post test, berdasarkan angket yang digunakan untuk mengukur respon peserta didik terhadap penerapan strategi yang digunakan menunjukan bahwa peserta didik memberikan tanggapan psoitif terhadap penerapan strategi please didalam menulis recount text. Penggunan strategi please dalam kegiatan menulis sangatlah effektif.penggunaan strategi ini bisa dipakai untuk kegiatan menulis peserta didik disekolag. Khusunya kegiatan menulis tesk atau paragraf yang panjang. Penggunaan strategi ini sangat membantu peserta didik dalam mengevaluasi kembali tuliasn yang telah mereka buat. Meskipun begitu, dalam proses pelaksanaanya, guru haru tetap memperhatiakan peserta didik yang sedang menulis guna memberikan arahan atau sebagai fasilitator bagi peserta didik bila mereka menenemukan masalah. Dalam pelaksanaan prosedurnya, peserta didik juga sering kali menemui kesulitan dalam membahasakan ide mereka kedalam Bahasa target atau yang bukan merupakan Bahasa serari-hari mereka, dalam hal ini Bahasa Inggris, sehingga selain membantu mengevaluasi hasil kerja peserta didik, guru juga harusnya dapat membimbing peserta didik untu dapat membahasakan ide mereka dengan baik. Penggunaan strategi please ini sangat baik untuk meniningkatkan kemampuan menulis peserta didi sehingga peneliti menyarankan para guru 
untuk menjadikan strategi ini sebagai strategi alternative jika peserta didik mereka mengalami kesulitan dalam menulis paragaf.

\section{Daftar Pustaka}

Arsyad, A. (2016) 'Jurnal Dimensi Pendidikan Dan Pembelajaran Vol.5 Januari 2016|29', Jurnal Dimensi Penididikan Dan Pembelajaran, 5, Pp. 29-37.

Hasil, M. Et Al. (2012) 'Jurnal Pendidikan Ipa Indonesia Pembelajaran Science-Edutainment Berbantuan Media', 1(2), Pp. 192-197.

Martha, N. And Situmorang, Y. (2018) 'Meningkatkan Kemampuan Menulis Siswa Melalui Teknik Guiding Questions', Journal of Education Action Research, 2(2), Pp. 165-171. Available At: Https://Ejournal.Undiksha.Ac.Id/Index.Php/Jear/Index.

Puspitasari, E. H. And Rustono, H. B. (2014) 'Peningkatan Keterampilan Menulis Kembali Dengan Bahasa Sendiri Melalui Media Film Dongeng', Jurnal Pendidikan Bahasa Dan Sastra Indonesia, 3(1), Pp. 1-8.

Rahmayanti, V. (2016) 'Pengaruh Minat Belajar Siswa Dan Persepsi Atas Upaya Guru Dalam Memotivasi Belajar Siswa Terhadap Prestasi Belajar Bahasa Indonesia Siswa Smp Di Depok', Sap (Susunan Artikel Pendidikan), 1(2), Pp. 206-216. Doi: 10.30998/Sap.V1i2.1027.

Sholichah, A. S. (2018) 'Teori-Teori Pendidikan Dalam Al-Qur'an', Edukasi Islami : Jurnal Pendidikan Islam, 7(01), P. 23. Doi: 10.30868/Ei.V7i01.209.

Sismulyasih Sb, N. S. S. (2015) 'Peningkatan Keterampilan Menulis Manuskrip Jurnal Ilmiah Menggunakan Strategi Synergetic Teaching Pada Mahasiswa Pgsd Unnes', Primary: Jurnal Pendidikan Guru Sekolah Dasar, 4(1), P. 64. Doi: 10.33578/Jpfkip.V4i1.2724.

Wiyanto, A. (2006) Terampil Menulis Paragraf. Jakarta: Pt Gramedia Widiasarana Indonesia. 